\title{
Hyperbary - the common roots of treatment of people and exploration of sea depths
}

\author{
Piotr Siermontowski ${ }_{\text {ABCDEFG }}$, Ewa Zieliński ${ }_{\text {ABCDEFG }}$, Romuald Olszański ${ }_{\text {ABCDEFG }}$ \\ ${ }^{1}$ Department of Marine and Hyperbaric Medicine, Military Medical Institute \\ ${ }^{2}$ High School of Bydgoszcz
}

\begin{abstract}
Elevated ambient pressure is inseparable from exploration of sea depths. The first attempts to design underwater devices almost immediately followed the construction of vehicles to navigate the sea surface. However, it took decades to design a land-based model of hyperbaric conditions and apply them for the treatment of various diseases. Nowadays, hyperbaric therapy is a recognized therapeutic method, which enables the treatment of diving and other underwater accidents. Thanks to long-standing technological advances, medicine and exploration of sea depths have met.
\end{abstract}

Key words: hyperbary, history of hyperbaric therapy, hyperbaric therapy, diving, diving accidents

About $71 \%$ of the Earth's surface is covered with water. Life on Earth started in oceans; there are however no confirmed data regarding the origin of seawater. Oceans are inhabited by much more living organisms than the Earth's land. There is no life without water. Without water, the Earth would be a barren wasteland characterized by extremely high daily temperature fluctuations.

The possibility to unravel the secrets of the underwater world is a triumph of human persistence, curiosity and inventiveness. Moreover, the capacity to "oppose" the laws of physics, such as the BoyleMoriotte, Charles', Dalton's or Henry's Law, each time we dive is a victory of humans over natural laws and an excellent example of cooperation between Man and Nature.

The other reasons for fathoming this foreign, fascinating world were curiosity, love of adventures, craving for exploration and hopes for finding valuable items [1]. Looking at the history of the oldest finds, it can be assumed that diving became a profession already in $4500 \mathrm{BC}$. The oldest pearl and mother-of-pearl ornaments come from Babylon. Greeks also "held their breaths" under water (2500BC). In 450 BC, Scyllias, a Greek diver, looked for underwater treasures. In the Iliad, Homer described smashing of Hector's chariot and transformation of its drivers into divers. About the same time, the first attempt was made to dive in a diving bell [2]. Moreover, divers became „weapons" of ancient times. Aristotle, who lived between 384-322 $\mathrm{BC}$, was interested in sea depths and already knew that sponges were animals and not plants. He also described the use of diving bells by Alexander the Great in 332 BC during the siege of Tyre.

Rome was not such a patron of science and technology as ancient Greece; nevertheless, Roman writings include the descriptions of diving devices. In his Natural History dated 77BC, Plinius described the diving equipment of those times.

In the Middle Ages, the development and interest in diving slightly slowed down. About 1500, Leonardo da Vinci drew a breathing device consisting of a leather helmet with spikes and flippers, i.e. gloves. In 1692, Denis Papin hit on an idea to pump air into a bell using leather bellows; yet the idea was never carried out. Edmund Helley (1656 - 1742) was the first to build a diving bell in a container with compressed air. In 1715, John Lethbridge constructed a diving barrel; in 1770, Freminet invented a leather suit and a copper helmet with an illuminator connected with the container with compressed air, which was carried on the diver's back. In 1787, a German inventor Klingert designed a protective diving suit with a helmet and wooden containers for regulating the depth of diving. Some brilliant inventions- patents arose in the 19th century. In 1819, Augustus Siebe designed a standard diving apparatus, i.e. a suit with a helmet and heavy boots; the helmet was supplied with air directly from the surface. His device was the basis for a classic diving equipment.

Parallel with the above inventions, the technology using pressure devices was developed. In 
1841, Trigger used a caisson to sink to the bed of Loire. Since then, the caisson technology became a standard for constructing bridges and tunnels.

In 1855, Joseph - Martin Cabirol from Bordeaux constructed Cabirol's diving suit. Five years later Benoit Rouquayrol patented a regulator of breathing gas inflow. Together with August Denayrouze he designed the first diving device with a pressure tank.

In 1878, Paul Bert published „La pression barometrique", which summarised the entire knowledge regarding the physiology of hyperbarism; moreover, the publication clarified the toxic effects of oxygen at large depths and proved that in the body under pressure nitrogen accumulated in blood. Furthermore, Bert introduced the term of , caisson disease", which is the oldest and still valid name of baropathology known in medicine. In 1907, Haldane calculated and published the first decompression tables and became a precursor of decompression research. The studies for military purposes (divers-saboteurs, "living torpedoes", evacuation of submarine crews) and devices constructed by Gagnan and Cousteau enabled free diving, called scuba diving. Hans Hass, a pioneer of underwater photography, or „underwater journalism”, popularized the underwater world already before the Second World War. Thanks to the inventions by Gagnan and Cousteau, diving became accessible for everyone. Since 1950, diving has evolved towards mass sports. Further improvements in equipment allow to dive easily, comfortably and increasingly safe. Nevertheless, divers and underwater workers have still been at risk of numerous diseases and diving injuries. The first descriptions of diseases are associated with work in caissons and complaints of bridge builders in New York. In 1885, an English engineer C.W. Moir was the first to use a pressure chamber for the treatment of caisson workers building the Hudson tunnel in New York, who suffered from caisson disease. Prior to the use of hyperbaric chambers, the average death rate was 1 per month as the workers were exposed to 2.41 bars. The novel therapy significantly reduced the mortality rate. Ten years later, the same inventor designed another pressure chamber during the construction of the Blackwell tunnel in London and the treatment was found to be effective. In 1913, the Drager Company constructed a foldaway one-person decompression chamber.

The first hyperbaric chamber called a domicillium, which was used for "healing" purposes was designed by Henshaw in England in 1662. The constructor assumed that acute diseases should be treated under high pressure while chronic illnesses under low pressure [3]. In his chamber, pressure was controlled with valves, which was a novelty. The results of his experiments are not fully known, as the method did not attract much attention of the scientific circles.

The innovative methods of therapy were of no interest, which is best visible in the fact that nobody entered the competition with awards advertised by the Dutch Society of Science in Haarlem in 1783 .

Fifty years later, in 1832 Tatarie presented his therapeutic suggestions of therapy to the French Academy of Sciences and created "the Pneumatic Centre" in Montpellier. The status of this institution is evidenced by the fact that among its employees were James Watt and Hymphry Davy. During the next years, hyperbaric chambers were continuously improved and applied not only for the purposes of health-resorts but also for treating divers and caisson workers. Initially the therapy was used intuitively, i.e. compression was applied until the patient's condition improved followed by decompression. The approach to the therapy was changed thanks to works of Paul Bert and Haldane, which laid foundations for real hyperbaric therapy in decompression accidents.

In the therapeutic centres of the 18th and 19th century, patients were treated with compressed air under the pressure of 2-3 atmospheres. Under such conditions, the therapeutic effect was inferior compared to cases in which $100 \%$ oxygen was used under atmospheric air; nevertheless, there are descriptions of spectacular effects of therapy, particularly in respiratory diseases.

Hyperbaric therapy with pure oxygen has developed simultaneously with air hyperbarism since the discovery of oxygen. In 1775, Priestley, one of the co-discoverers of oxygen, highlighted the therapeutic possibilities of this element basing on higher intensity and life of the candle flame". Since 1907, oxygen has started to be used to supplement the traditional therapy of numerous diseases and an interest in its use continued. The crowning achievement of those years was the constructions of Orville Cunningham from the United States, who developed therapies with oxygen hyperbarism (interwar period) in cardiac and respiratory diseases using increasingly bigger hyperbaric objects; the largest of them was a spherical "hospital", over 20 meters in diameter holding 36 double patient's rooms. 
In 1868 ( Linas and Limousin) and then in the early years of the 20tieth century, the first successful attempts were made to treat carbon monoxide poisonings with hyperbaric oxygen. In the 50-ties, Ide Boeremia, a Dutch surgeon, performed congenital cardiac defect corrective surgery in the hyperbaric chamber filled with oxygen, which allowed to prolong the procedure under the conditions of circulatory arrest. In 1960, he carried out an experiment which demonstrated that animals could survive several hours after being deprived of morphotic plasma elements, once elevated pure oxygen conditions were provided. In 1954, Churchill and Davidson used hyperbaric oxygen to increase the susceptibility of neoplasms to radiation. In 1961, Boerema and Brummelkamp applied hyperbaric oxygen for the treatment of gas gangrene in humans.

In the 60-ties, interests in surgeries in hyperbaric chambers markedly decreased, which was associated with the invention of a heart-lung machine; many cardiac surgeons abandoned the use of oxygen hyperbarism. Due to a sudden decrease in the number of hyperbaric chambers, lack of any legal regulations and guidelines on indications and contraindications for hyperbaric therapy, the research was initiated to formulate the scientific basis of this medical discipline and rational standards of its use [4].

In 1975, during the first international conference in San Antonio, in which hyperbarism specialists took part, the first textbook about hyperbaric medicine was presented containing strict indications for the use of hyperbaric therapy. In the 80-ties and 90 -ties of the 20tieth century, many experimental and clinical studies were carried out and the scientific basis were formulated for the use hyperbaric therapy in cases of difficult wound healing, burns, crush syndrome and osteitis.

In 1994, the European Consensus Congress of Hyperbaric Medicine was held in Lille during which the list of indications for hyperbaric therapy, standards of personnel training and equipment of hyperbaric centres were established.[5]

However, dark episodes in the development of hyperbaric therapy, oxygen therapy in particular, have to be mentioned. Hyperbaric oxygen is an excellent oxidant; therefore, the risk of fire in its atmosphere increases. A series of fires of hyperbaric chambers with numerous fatalities was one of the reasons that inhibited the development of this therapy at the turn of the 19th and 20tieth century. In the interwar period, the stagnation was also observed in Poland. In the 60ties (after another cham- ber fire in Gdynia), the development of hyperbaric therapy was reinitiated in Poland. The administration of oxygen through a tight mask during the chamber filling with air was of pivotal importance.

Lack of learning from the mistakes of others resulted in the Apollo tragedy in January 1967. The command module of the spacecraft was filled with pure oxygen. During a ground rehearsal, sparking of wires, followed by violent fire occurred, which claimed lives of the entire crew.

Hyperbaric medicine is a relatively dynamically developing branch of medicine. At present, therapeutic hyperbarism is a recognized treatment method.

Hyperbaric therapy enables the treatment of diving and other underwater-associated accidents. Thanks to the long-standing development of technology, medicine and exploration of sea depths met. The number of specialist centres dealing with hyperbaric therapy is increasingly high. Moreover, the indications for therapy with hyperbaric oxygen increase as new aspects of hyperbaric oxygen effects on the human body are discovered. Numerous worldwide studies are being carried out concerning the use of this therapy in various clinical conditions.

Hyperbaric oxygen therapy involves the supply of increased amounts of oxygen to the affected tissues and organs. Patients in hyperbaric chambers breath in 100\% oxygen at increased ambient pressure ( $>1$ ATA). At the sea level, the concentration of oxygen in plasma is about $3 \mathrm{ml} / \mathrm{l}$. In order to maintain proper cell metabolism, tissues at rest require about $60 \mathrm{ml}$ of oxygen per 1 litre of blood. When patients breathe with $100 \%$ oxygen at the pressure of 3 ATA, the amount of oxygen dissolved in plasma increases to almost $60 \mathrm{ml} / \mathrm{l}$ of blood and virtually covers full tissue requirements without oxygen transported by haemoglobin, which is essential in patients poisoned with carbon monoxide or those with severe anaemia [6].

It should be emphasised that hyperbaric oxygen therapy (except for poisonings and gas embolism) is supportive and not alternative to surgical treatment or antibiotic therapy, particularly in cases of difficult wound healing and infected acute wounds [5]. Thanks to its direct inhibition of the growth of anaerobic bacteria and stimulation of bactericidal properties of leukocytes fighting aerobic bacteria, hyperbaric oxygen therapy is an essential element supporting the treatment of infections. When the body does not respond to surgical wound repair combined with target antibiotic therapy initiated 
within 48 hours, hyperbaric oxygen therapy should be considered [7]. Noteworthy, diabetes mellitus has become a global epidemic [8]. Its complications involving foot ulcerations, secondary infections and limb amputations are extremely expensive to treat [9]; $65 \%$ of patients with foot ulcerations are also affected by neuropathy, deformities or injuries [10]. Moreover, there are reports of successful treatment of osteitis and osteomyelitis [11].

The use of hyperbaric therapy can be divided into four large groups:

1. Treatment of local and generalised ischaemia

2. Treatment of gas embolism

3. Other therapeutic applications

4. Non-therapeutic applications.

The first group of indications derives from „Domicillium" developed by Henshaw. Generally, oxygen therapy at increased pressure is an excellent adjunctive treatment; in cases of carbon monoxide poisonings, it is the essential treatment option.

The range of indications for hyperbaric therapy is increasingly wide. The possibility to deliver higher amounts of oxygen to the tissues, not only bound with haemoglobin but also physically dissolved in plasma, cannot be overestimated in the treatment of anaemia and hypoxia. In emergency medicine, hyperbaric therapy of hypoxia is used in cases of carbon monoxide poisonings, as already mentioned. The list of indications in the other branches of medicine is much longer.

Therapy in question is mainly used for wound and burn healing as well as frostbites and is the most effective method to treat anaerobic infections. Moreover, the method is applied for the treatment of diabetic foot, lower leg ulcerations and other pathological defects predominantly associated with ischaemia in vascular diseases. It is used in cardiology (ischaemic syndromes), pulmonology (abscesses and fungal infections), laryngology, particularly in cases of sudden deafness and acoustic trauma, in orthopaedics and traumatology in cases of purulent osteitis, difficult healing of osteosynthesis and extensive traumas of soft tissues, urology for the treatment of Fournier's fasciitis (gangrene) and ischaemia-related diseases. Skin injuries and infections, which both dermatology and surgery are concerned with, are the main indications for hyperbaric oxygen therapy.

Studies regarding the use of hyperbaric oxygen in ischaemia of the nervous system, especially of the CNS associated with vascular changes have been carried out for many years; however, due to discrepancies in their findings, explicit positive or negative effects cannot be established.

The second group of indications involves emergencies ( life-threatening conditions). Gas embolism in veins, yet particularly in arteries, can be caused by many factors. The best known are cases are those of iatrogenic venous air embolism induced by the introduction of some air during injections, infusions or vein openings in surgeries performed in the Trendelengurg position. The second group of air embolisms is related to lung parenchyma injuries. The most common causes include trauma associated with exposure to explosive shock waves and pressure trauma in individuals exposed to sudden pressure changes (pilots, divers). This is arterial air embolism. The third group of causes is connected with diving and aviation, although only to some extend. Gas embolisms in this group are caused by denaturation of body fluids and tissues due to changes in ambient pressure, leading to the occurrence of air bubbles in those tissues and fluids. The last and rarest group of causes of gas embolism is related to intentional or otherwise introduction of various gases into body cavities or vessels during accidents at work, in cases of self-inflicted injuries or criminal cases.

Irrespective of the way the air gets to the vessels, especially in cases of arterial embolism and CNS or retina embolism, urgent compression is necessary. Its purpose is to reduce instantly the diameter of a gas bubble, which can pass through the capillaries to the venous flow or shift further decreasing the ischaemic area. Secondly, hyperbarism, oxygen hyperbarism in particular, counteracts tissue ischaemia within the region of embolism. Thirdly, appropriate decompression prevents increases in already present bubbles and formation of new ones. In this group of indications, the therapy requires completely different profiles of compression and decompression as compared to the other groups; moreover, high skills of the attending staff and high technical standards of equipment are essential.

The third group of indications unrelated to ischaemia or embolism is still under research. There are reports describing the attempts (successful???) to treat mental disorders, infantile cerebral palsy or other somatic diseases using oxygen hyperbarism; nevertheless, the method is not routinely applied.

The final group of indications that are poorly related to medicine is associated with increasingly wide availability of hyperbaric centres, lower person-exposure prices and fashion. The precursors 
in this field were "oxygen bars". At present, their number decreases and more advanced and sophisticated methods to apply increased doses of oxygen are being searched for. Recently, hyperbaric oxygen and hyperbaric air have been increasingly used in quickly developing cosmetology. The attempts to treat cellulite or improve appearance are a source of amusement to the majority of physicians. Nevertheless, due to social demands, the therapy is applied, which can be compared to the use of homeopathic drugs. The efficacy of both "therapies" is identical. However, in this group, there are single effective applications of hyperbaric therapy, e.g. poisonings with alcohol metabolism products (hang-over) or positive effects of oxygen hyperbarism on metabolism.

Possible complications of HBO therapy can be divided into those resulting from pressure trauma (e.g. pressure trauma of the middle ear, paranasal sinuses, internal ear, lungs, teeth), related to oxygen toxicity (CNS, lungs) and adverse effects affecting eyes (short-sightedness, cataract) or limitations associated with claustrophobia and chamber-related anxiety $[8,12]$

The final link between diving and therapeutic hyperbarism is connected with the skills of attending physicians. Throughout history, as already been described in the first part, the treatment was provided by physicians of various specialties or even engineers ( who wanted to help caisson workers). Due to the lack of preciously determined indications, hyperbaric therapy has not been included in the canon of any medical speciality for years. Thanks to a wider use of diving bells, caissons, Siebe's diving suits, hyperbaric therapy has been permanently combined with diving medicine. Moreover, the military use of underwater navigation has bound the therapy with military medicine. Since all diving or hydrotechnical activities are connected with water, a wide panel of knowledge regarding diving and hyperbaric medicine was included in the curriculum of Marine and Tropical Medicine. In Poland, this speciality was for some years replaced by Medicine of Transport ( a single-degree speciality) yet the former name was restored; at present, it is the only speciality, which deals with hyperbaric medicine to such an extent. Recently, interest in this form of treatment has been observed among anaesthesiologists; nevertheless it is not found in any speciality programme of Anaesthesiology and Intensive Therapy ( except for some information about the treatment of poisonings).
Considering an increasingly long list of indications for hyperbaric therapy in various medical specialities, all or almost all specializing physicians should be trained in possible uses of this therapy within the field of their speciality. However, the cases requiring non-standard methods, high pressures or changes in respiratory parameters during treatment should be managed by specialists in Marine and Tropical Medicine.

\section{References:}

1. Petriconi V, Wieland F. Podwodny świat roślin i zwierząt. 2002; 7.

2. Kuisys K. Faszination Tauchen Historie. 2002; 8.

3. www.hiperbaria.wroc.pl -cited at 06.062015.

4. Sieroń A, Cieślar G. Zarys ...,op. cit., pp. 15-21.

5. Dauwe P, Pulikkottil, Benson J. M.D, Lavery, Lawrence DPM., Stuzin, James M. M.D., Rohrich, Rod JMD. Does Hyperbaric Oxygen Therapy Work in Facilitating Acute Wound Healing: A Systematic Review Plastic \& Reconstructive Surgery. 2014; 133(2): 208-215.

6. Leach RM, Rees PJ, Wilmshurst P.Hyperbaric oxygen therapy, 1998; 317(7166): 1140-1143.

7. MacFarlane C, Cronje FJ, Benn CA. Hyperbaric Oxygen in Trauma and Surgical Emergencies, J R Army Med Corps 2000; 146: 185-190.

8. Zieliński E, Grobelska K, Galarowicz O. PolHypRes": Zespół stopy cukrzycowej, jako istotny problem terapeutyczny i ekonomiczny. 2014; 48(3): 7.

9. Daly MC, Faul J, J.S.Steinber: Hyperbaric oxygen therapy as an adjunctive treatment for DFU: A Comprehensive Revievw with case studies, Wounds 2010; 22 (1): 1-2.

10. Głuszek S, Rączka M, Zagórska S. Stopa cukrzycowa, jako trudny interdyscyplinnarny problem kliniczny, Studia medyczne Akademii Świętokrzyskiej, Kielce 2007, vol. 8.

11. Zieliński E, Lipińska A, Grobelska K, Siermontowski P. „PolHypRes”: Opis przypadku pacjentki leczonej w Centrum Hiperbarii Tlenowej i Leczenia Ran w Bydgoszczy.2015; 50(1): 25.

12. Szymańska B, Kawecki M, Knefel G. Kliniczne aspekty Hiperbarii Tlenowej, Wiadomości Lekarskie 2006, LIX, 1-2: 105-109.

\section{Corresponding author:}

Piotr Siermontowski MD, PhD

Department of Marine and Hyperbaric

Medicine, Military Medical Institute 